\title{
Suicide behavior among patient with mental disorder
}

\author{
Catur Budi Rahayu ${ }^{1}$, Siti Nurjanah ${ }^{2}$ \\ ${ }^{1}$ Student of Nursing Study Program Faculty of Health Science, Universitas Muhammadiyah Purwokerto, Indonesia \\ ${ }^{2}$ Psychiatry of Nursing Department, Universitas Muhammadiyah Purwokerto, Indonesia
}

\begin{tabular}{l}
\hline \hline ARTICLE INFO \\
\hline Article history: \\
Received: August 9, 2020 \\
Revised: August 20, 2020 \\
Accepted: August 30, 2020 \\
\hline
\end{tabular}

Keywords:

Suicide; Self-harm behavior questions; Mental disorders

\begin{abstract}
Suicide is an act consciously taken by a person to end his life. The phenomenon of suicide in Indonesia is increasingly worrying. Indonesia, as a country that adheres to a culture of collectivity, also has a high suicide rate. WHO estimates that in 2020 the suicide rate in Indonesia could reach 2.4 percent of 100,000 people if it does not get serious attention from various parties.Suicide is one of the effects of mental disorders that are in the global spotlight today. This study aims to describe suicidal behavior in patients with mental disorders. This is a descriptive study. The research subjects were schizophrenic they were treated in the Installation of Integrated Mental Health Service in Banyumas Hospital. The data were collected using the Self Harm Behavior questionnaire. Result of the study is suicidal behavior are the desire to die, trying with sharp objects, hitting selves, hitting glass and drinking poisonous substance, and jumping from high building.
\end{abstract}

This work is licensed under a Creative Commons Attribution 4.0 International License.

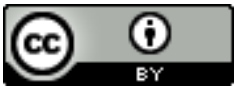

\author{
Corresponding Author: \\ Catur Budi Rahayu, \\ Student of Nursing Study Program Faculty of Health Science, \\ Universitas Muhammadiyah Purwokerto, \\ Jl. Raya Dukuh Waluh PO Box 202 Purwokerto, Jawa Tengah, Indonesia \\ Email: caturbudirrahay@gmail.com
}

\section{INTRODUCTION}

The The data from the World Health Organization (WHO) in 2017 indicated that every year as many as 800,000 people die as a result of suicide. It means in each 40 seconds one person dies of suicide [1]. Among the cases, $78 \%$ of the global suicide is in low- and middle-income countries. Individuals with schizophrenia who attempt to suicide are more likely to use more lethal methods in their trials; they have a strong desire to die, and perform repeated attempts.

Patients with more significant and persistent negative symptoms appear to have a lower risk of suicide [2]. More than $90 \%$ of people who commit suicide suffer from psychological disorders.In 2017, a case of suicide in a psychiatric patient was also reported at Madani Hospital, North Palu by hanging himself in the bathroom [3]. Patient at the Regional General Hospital (RSUD) Dr. H Moch Ansari Saleh Banjarmasin was also found hanging himself in the room where the victim was being treated [4]. While at the Banyumas Hospital Mental Health Service Installation, the same case occured in 2017.

\section{RESEARCH METHOD}

This is a descriptive type of research, aimed to describe the suicidal behavior in mental patients. The study was conducted in a week (27 November - 2 December 2019). The population in this study was 110 respondents, which is sampled with total sampling and obtained 40 respondents. The research subjects were schizophrenic patients aged 20-40 years old. They were treated in the Installation of Integrated Mental Health Service in Banyumas Hospital. The data were collected using the Self Harm Behavior questionnaire. The analysis used the univariate analysis, functioning to describe the characteristics of each variable [5]. The general characteristics in this study are age, gender, education, occupation. The variables studied were suicide ideas, cues, threats, and attempts. 


\section{RESULTS AND DISCUSSIONS}

3.1. The results of the study are described as follows:

Table 1. Characteristics of patient respondents with suicide behavior

\begin{tabular}{lcc}
\hline Characteristics & Frequence & Procentage \\
Age & 4 & $10 \%$ \\
$20-22$ yrs & 6 & $15 \%$ \\
$23-25$ yrs & 6 & $15 \%$ \\
$26-28$ yrs & 5 & $12.5 \%$ \\
$29-32$ yrs & 12 & $30 \%$ \\
$33-36$ yrs & 7 & $17.5 \%$ \\
$37-40$ yrs & & \\
Nursing diagnosis & 17 & $42.5 \%$ \\
RPK & 23 & $57.5 \%$ \\
Haluccination & & \\
Gender & 16 & $40 \%$ \\
Male & 24 & $60 \%$ \\
Female & & \\
Education & 16 & $40 \%$ \\
Elementary & 11 & $27.5 \%$ \\
Secondary & 21 & $30 \%$ \\
High school & 1 & $2.5 \%$ \\
D3/S1 & & \\
Occupation & 16 & $40 \%$ \\
Housewives & 5 & $37 \%$ \\
Self-employed & 1 & $2.5 \%$ \\
Private employee & 0 & \\
Civil servant & 8 & \\
Others & & \\
\hline
\end{tabular}

Based on Table 1. The respondents' average age is 31 years old. From the nursing diagnoses, (42.5\%) respondents have a diagnosis of RPK and $(57.5 \%)$ respondents are with hallucinations. Based on their gender, there are more female $(24, / 60 \%)$ than male, $16(40 \%)$. Their education level of the most respondents $(16$ or $40 \%$ ) is only at elementary school, and most of them (16 or $40 \%)$ are housewives.

Table 2. Distribution of the respondents' level of suicidal behavior $(n=40)$

\begin{tabular}{lcc}
\hline Suicidal behavior & Frequence & Procentage \\
\hline No signs & 23 & $57.5 \%$ \\
Suicide idea & 6 & $15 \%$ \\
Threath & 3 & $7.5 \%$ \\
Signs & 5 & $12.5 \%$ \\
Trials & 3 & $7.5 \%$ \\
\hline
\end{tabular}

As seen in the table 2, the respondents who had no sign of suicidal behavior were dominat, 23 (57.5\%) Those showing a suicidal idea were $15 \%$ (6 patients), fewer of them (12,5\% or 5 patients) indicates suicidal signs, and the rest of $7.5 \%$ ( 3 persons) have attempted to commite suicide.

Table 3. Incidence of suicide behavior from the method $(n=13)$

$\begin{array}{lcc}\text { Suicidal behavior } & \text { Frequence } & \text { Procentage } \\ \text { Desire to die } & 2 & 15.4 \% \\ \text { Sharp objects } & 2 & 15.4 \% \\ \text { Hit the glass } & 3 & 23.1 \% \\ \text { Hit self } & 2 & 15.4 \% \\ \text { Poison } & 3 & 23.1 \% \\ \text { Jumping } & 1 & 7.7 \% \\ \text { From high building } & 13 & 100 \%\end{array}$


Seen on on Table 3, the data on the incidence of suicidal behavior are the desire to die, trying with sharp objects, hitting selves, hitting glass and drinking poisonous substance, and jumping from high building.

\subsection{Discussion}

In this study, respondents who reported suicidal idea were $6(15 \%)$ respondents. The idea of suicide is determining factor for the suicidal act, as another finding (Ibrahim et al., 2010) in Malaysia, it revealed that almost half of the respondents had suicidal ideas that were at risk of suicidal behavior. Suicide behavior in the form of threats to kill himself in this study was obtained in 3 respondents (7.5\%). Stated that the threat of suicide can lead to suicide in the future, whereas an immediate threat can carry a high likelihood of action in the near future [6]. Signs of suicide were indicated in 5 respondents $(12.5 \%)$. In this condition the patient may have had the idea of ending his life, but not accompanied by threats and suicide attempts. The suicide attempts were shown among 3 (7.5\%) respondents. According to Nock, et al (2010), in several countries, $60 \%$ of the transition from idea to plan and suicide attempts occurred within one year after the emergence of suicidal thoughts.

Data on the incidence of suicidal behavior, according to the method of suicide, showed that the respondents who had a desire to die, tried to commit the suicide with a sharp object, tried by hitting the self are $2(15.4 \%)$ for each category. Three respondents $(23.1 \%)$ had tried a suicide, by hitting the glass, and a patient tried it by jumping from high building. Another research had also been conducted at the Regional Hospital of Dr. Pirngadi Medan in 2006-2011 among the patients with suicide attempt using poison. The result showed that based on the type of poison used, it is the type of poison of code X68\% (based on ICD X), in the form of pesticides such as Baygon, Soffel, rat and pest poisons, with a proportion of $61.2 \%$.

\section{CONCLUSION}

Based on the results of the research, among 40 respondents, it was found that their suicidal behavior included a desire to die, suicide trial with sharp objects, with hitting the self, with hitting glass, with drinking poison and with jumping from high buildings.

\section{REFERENCES}

[1] Ratih and D. H. Tobing, "Konsep Diri Pada Pelaku Percobaan Bunuh Diri Pria Usia Dewasa Muda Di Bali," Jurnal Psikologi Udayana Program Studi Psikologi, vol. 3, no. 3, p. 430-444, 2016.

[2] WHO SEARO, Mental Health Status of Adolescents in South-East Asia : Evidence for Action, WHO Regional WHO, 2017.

[3] B. Sadock, Ruiz and P. Kaplan, Comprehensive Textbook of Psychiatry, 9th ed., Lippincott Williams and Wilkins, 2017.

[4] Anonim, "Berita Daerah," 7 Juli 2019. [Online]. Available: https://www.jpnn.com/news/pasiengantung-diri-di-kamar-mandi-rumah-sakit?page $=1$.

[5] A. Biromo, "Uji Validitas dan Reliabilitas Instrumen Self-Harm Behavior Queationnare (SHBQ) Versi Bahasa Indonesia," FKUI, 2015.

[6] Sugiyono, Metode Penelitian Kuantitatif, Kualitatif, dan R\&D, Bandung: CV Alfabeta, 2017.

[7] Silverman, "Rebuilding the Tower of Babel: A Revised Nomenclature for the Study of Suicide and Suicidal Behaviors Part 2: Suicide-Related Ideations, Communications, and Behaviors, SuicideandLife-Threatening Behavior," vol. 37 , no. 3, p. 264-277, 2009. 